the eruption of the incisor teeth-the child of our primitive ancestors was adapted to pierce, to gnaw, and to suck the fruits and shoots with which it was supplied and as some few shreds of cellulose were sure to be swallowed then indeed the transmission of cellulose was a function early imposed upon the intestines, while the enormous amount of gnawing and sucking which must have been necessary for the primitive child to extract a sufficiency of nutriment to supplement the decreasing supply of milk amply accounts for an enormous development of the jaw muscles. When we contrast this with the modern pap diet from which every particle of cellulose which demands mastication has been most carefully eliminated we observe that the change in the character of the food begins with weaning and is, I believe, amply sufficient to account for the marked difference in the muscularity of the masticatory apparatus and stomach. I am, Sirs, yours faithfully,

Wimpole-street, Dec. 12th, 1904.

J. Sim WALLACE

\section{CANCER OF THE CERVIX COMPLICATING LABOUR.}

To the Editors of THE LANCET.

SIRS, - I would not have ventured to write again on this subject were it not necessary for me frankly to apologise and to express my regret to $\mathrm{Dr}$. Herbert $\mathrm{R}$. Spencer for my careless statement that at the recent discussion at the Obstetrical Society he did not bring forward a case of his own to support his view that the Porro operation was safer than conservative Crsarean section in inoperable cases of cancer of the cervix complicating labour. Dr. Spencer did relate such a case, with a successful result, and 1 much regret that I confused it with another case where, owing to labour being obstructed by cervical cicatrices, he had performed a Porro-Cæsarean operation two years after amputation of a cancerous cervix. This fact strengthens his argument and to that extent weakens mine. Dr. Spencer and I have gone carefully over Porro's report and have extracted from it all the PorroCæsarean operations with extra-peritoneal treatment of the stump, and we find that there were in all 35 cases, with 12 deaths $-34 \cdot 3$ per cent. No statistics of conservative Cæsarean sections are given.

As regards Sarwey's statistics-viz., 33 cases of conservative Cæsarean section, with a mortality of 60 per cent., and 24 cases of Porro-Cæasarean operations with a mortality of 54 per cent., Dr. Spencer says that the latter group of cases includes some hysterectomies with intraperitoneal treatment of the stump. I quote Sarwey's exact words : "Fälle von Porro's Kaiserschnitt (Werth, Leopold, Fehling, Zweifel, Kehrer), bei inoperablem Carcinom ohne weitere operative Eingriffe niedergelegt," As Sarwey gives neither details nor references it is not possible to be sure whether he speaks of Porro-Cæsarean operations in the original meaning with the stump treated extraperitoneally, as I assumed, or whether he is adopting the looser meaning of "Porro" as now used in "foreign statistics"-e.g., Porro Report, 1901-which includes not only intra- and extra-peritoneal hysterectomies but even panhysterectomies. Dr. Spencer has drawn my attention to the fact that $Z$ weifel has published two cases of Cæsarean hysterectomy with intraperitoneal treatment of the stump, with fatal results, as one would expect in such cases as these. If these are included among Sarwey's cases the statistics cease to be of any comparative value for our present purpose.

Further experience will prove which operation is the safer and this correspondence is merely an attempt to clear up some of the doubtful points bearing on the subject. At present the statistics of published cases are distinctly in favour of Dr. Spencer's view, but the numbers are very small. I am, Sirs, yours faithfully, Amand Routh, M.D. Lond.

Manchester-square, W., Dec. 13th, 1904.

\section{ANOMALIES IN THE APPLICATION OF THE DUTCH PUBLIC HEALTH ACTS.} To the Editors of THE LANCET.

SIRS, - I was struck by an annotation under the above heading in The LANCET of Dec. 3rd, p. 1585, and I beg to offer some short remarks about it. You say that the chief inspectors are not bound to pay attention to what the chairmen of the municipal boards of health say and often enougn take no notice of their remarks. The natural consequence would be a great amount of dissatisfaction. Now I am one of these chief inspectors. There is not one in each of the provinces, as you state, but we are only four in the whole country and as such members of the Central Board of Health that sits in Utrecht. In this quality we hold a regular intercourse and meet very often. For my part of the business I never was aware of any amount of dissatisfaction in the way you mentioned and if such was felt in other parts of the country I ought to have heard it, but I never dicl. In fact, there is no serious dissatisfaction at all. Every organisation will have its defects and leave something to be wished for, and so does ours. But considering this organisation is new and the time of its working too short to be sure of its effects, it can fairly be said that the Public Health Act works well and will do so still more in the future. All the complaints in your annotation issue from the same source and there cannot be a serious reason to think that this bad meaning represents the prevailing opinion. Such trifling conflicts as are referred to in your annotation will happen always and everywhere and can only be considered as the results of a momentary misunderstanding. Complaints to this effect are merely superficial and personal and never reach to the very root of the question. The only one that touches the principles of the organisation is that concerning the chief inspector's preventing the boards from holding meetings to combat tuberculosis. This complaint was unjust, however. In dealing with the matter as he did my colleague was right, I believe. The municipal boards of health are part of the organisation and if they wish to act as such, not as private persons, they are bound to subject themselves to the regulations of the law. If they were allowed to disregard the supervision of the chief inspector and to assemble in a body of their own independent of that official the Act would be idle and the whole organisation would be endangered.

I would trespass too much on your space and also take too much of my own time if I dwelt longer on the subject, as I should willingly do, but I hope these few remarks will suffice to convince you that there is another manner of looking at the matter, and especially that there is no official apathy on our part or improperly clinging to "red tape." The British Empire has a high and well-deserved reputation for the management of public health and I should be very sorry if British readers could think that our country was acting so much in the wrong way as the annotation in your esteemed journal suggested. To prevent this I ventured to write to you. I am, Sirs, yours faithfully,

$$
\text { Dr. M. W. PyNAPPEL, }
$$

Chief Inspector of Public Health for the

Zwolle, Netherlands, Dec. 6th, 1904.

\section{LONDON AND COUNTIES MEDICAL PRO- TECTION SOCIETY.}

To the Editors of THE LANCET.

SIRS,-It may interest some of your readers to know that at its meeting on Dec. 9th the council of the London ana Counties Medical Protection Society decided to impose an entrance fee of $10 \mathrm{~s}$. upon all candidates elected members of the society on or after Jan. 1st, 1905, and until further notice. The annual subscription (10s.) remains unaltered. The council decided to take this step chiefly for these reasons. On Jan. 1st, 1904, the number of members (including dentists) on the books of the society was 2682. Since Jan. 1st, 1904, the new members elected (including dentists) number 579. The society's reserve fund is now in this position :-

\begin{tabular}{|c|c|c|c|c|c|c|c|}
\hline Present investments & & & & & & $\begin{array}{c}\stackrel{£}{1} \\
\ldots 1796\end{array}$ & $\begin{array}{cc}8 . & d \\
15 & 4\end{array}$ \\
\hline Awaiting investment & $\cdots$ & $\ldots$ & $\cdots$ & $\cdots$ & $\cdots$ & ... 600 & 0 \\
\hline $\begin{array}{lllll} & & & & \\
& \ldots & \ldots & \ldots\end{array}$ & ... & $\ldots$ & ... & ... & ... & ... & 7 \\
\hline
\end{tabular}

No similar society in England could afford to spend on each of its members as much money as could be so spent by the London and Counties Medical Protection Society.

For these reasons the council thinks that to require newly elected members to pay a small entrance fee is merely an act of bare justice to the members of the society who for years have exercised self-denial in order that the funds of the society might be placed on a fairly sound basis. The trustees of the saciety's reserve fund are Sir William $H$. 